\title{
Russian-Ottoman Border in the East Transcaucasia in the 20s-30s of the 18th century: Problems of Demarcation, Reaction of Frontier Communities
}

\section{Sharafetdin A. Magaramov \\ Dagestan Federal Research Center of the Russian Academy of Sciences. Makhachkala, Russia. Email: sharafutdin[at]list.ru}

\begin{abstract}
The paper analyses one of the issues of the eastern policy of Russia of the Peter's era, related to the creation of the Russian-Ottoman frontier on the territory west to the Caspian Sea. The difficulties in the process of carrying out demarcation in the border zone caused by the negative reaction of various actors in the border life are discussed. The author introduces a new source a historical map of the Caspian territories, on which the border between the Russian and Ottoman Empire is drawn; demarcation work, conducted by the committee, is shown. The study reveals that the Russian-Ottoman border line divided the communities of the East Transcaucasia without consideration of historical traditions of conducting economic activity and ethnocultural contacts, thus certain difficulties and unsteadiness occurred in the border zone. The reaction of the frontier participants make it possible, in general, to determine the attitude of the Caucasian and Persian political elites to the emergence of the Russian and Ottoman Empires in the Caucasus-Caspian region. The obtained scientific results are unique from the point of view of humanitarian knowledge, and they can be used for further development of various issues of the Caucasian foreign policy of the Russian and Ottoman Empires of the 18th century by Russian and foreign researchers.
\end{abstract}

Keywords

Persian Campaign of 1722-1723; Peter's Era in Russia; Russian-Ottoman Frontier; Western Caspian Region; Demarcation of Borders; Historical Map; Reaction of Frontier Communities

This work is licensed under a Creative Commons "Attribution" 4.0 International License 


\section{Российско-османское пограничье в Восточном Закавказье в 20-30-е гг. XVIII в.: проблемы разграничения, реакция пограничных сообществ}

\section{Магарамов Шарафетдин Арифович}

Дагестанский федеральный исследовательский центр Российской академии наук. Махачкала, Россия. Email: sharafutdin[at]list.ru

\section{Аннотация}

В статье проанализирован один из сюжетов восточной политики петровской России, связанный с возникновением российско-османского пограничья на землях к западу от Каспийского моря. Показаны трудности в процессе проведения демаркационных работ в пограничной зоне, вызванные негативной реакцией различных акторов пограничной жизни. Вводится в научный оборот новый источник - историческая карта прикаспийских территорий, на которой очерчена граница между Российской и Османской империями; показаны осуществляемые комиссией демаркационные работы. Проведенное исследование показало, что российско-османская пограничная линия разделила общества Восточного Закавказья без учета исторически сложившихся традиций ведения хозяйственной деятельности и этнокультурных контактов, и поэтому наблюдалась сложность и изменчивость в пограничной зоне. Реакция участников пограничной зоны позволяет в целом определить отношение кавказских и персидских политических элит к появлению в Кавказско-Каспийском регионе Российской и Османской империй. Полученные научные результаты с точки зрения гуманитарного знания носят уникальный характер и могут быть востребованы при дальнейшей разработке российскими и зарубежными ученымиисториками различных сюжетов кавказской внешней политики Российской и Османской империй XVIII в.

\section{Ключевые слова}

Персидский поход 1722-1723 гг.; Петровская Россия; российско-османское пограничье; Западный Прикаспий; демаркация границы; историческая карта; реакция пограничных обществ

Это произведение доступно по лицензии Creative Commons “Attribution” («Атрибуция») 4.0 Всемирная 


\section{Введение}

Персидский поход 1722-1723 гг. - последняя крупная внешнеполитическая акция Петра Великого, - привел к коренным геополитическим изменениям в Восточном Закавказье и на севере Сефевидского Ирана. В прикаспийской провинции кроме традиционно соперничавших между собой региональных держав, Османской империи и Сефевидского Ирана, появился новый политический «игрок» в лице молодой Российской империи. Появление петровской армии в прикаспийских областях привело к военно-дипломатическому противостоянию между Российской и Османской империями, разрешившееся подписанием Константинопольского договора 1724 г., по условиям которого державы договорились разделить сферы влияния в Восточном Закавказье и установить российско-турецкую пограничную линию.

B настоящей статье на основании богатой документальной базы из фондов федеральных и региональных архивов России, большинство которых впервые вводится в научный оборот, ставится цель - изучить процесс осуществления и проблемы в демаркации российско-турецкой границы на западном побережье Каспия, показать реакцию кавказских обществ на новый пограничный порядок, сложность и изменчивость пограничной жизни в регионе. Кроме того, в работе впервые вводится в научный оборот карта, составленная геодезистами Петровской эпохи, с указанием проводимых демаркационных работ в российско-турецком пограничье, выявленная автором данной статьи в фондах Российского государственного военноисторического архива.

\section{Основное содержание}

В результате последней крупной военной кампании Петра Великого Персидского похода, - город Дербент, являвшийся на протяжении более чем двух последних веков северным форпостом державы Сефевидов и оплотом их господства на Северном Кавказе, мирно сдался российским властям. Этому предшествовала то, что еще 15 августа 1722 г. в Дербент Петром I был отправлен подполковник Г. Наумов, которого горожане

«приняли с великою радостию... и были рады, что услышали о пришествии Е.И.В.» (РГАВМФ, ф. 233, оп. 1, д. 211, л. 209).

В это же время с моря к Дербенту подошла эскадра капитана фон Вердена. Дербентскому правителю (наиб) Имам Кули-беку и городской знати (юзбаши) от имени императора была подана грамота, за что они поблагодарили представителей российской военной власти. В донесении генерал-адмиралу Ф.М. Апраксину от 15 августа 1722 г. из устья реки Милюкент (совр. р. Рубас), где был разбит лагерь для российских войск, отмечалось, что «дербентские 
жители зело ожидают прибытия Его Императорского Величества в город свой, хотят поклонить под державу Его Величества» (л. 209).

Со взятием Дербента военный поход с личным участием императора был временно приостановлен. Однако продвижение российской армии на юг, в сторону Сефевидской державы, вдоль каспийского побережья было продолжено, но уже небольшими отрядами. Изменилась тактика продвижения российской армии. В конце 1722 г. отряду полковника П.М. Шипова удалось занять город Решт - главный город Гилянской провинции (РГАДА, ф. 9, оп. 4, д. 63, л. 621-623). В следующем году военная компания была продолжена, в июле 1723 г. российские отряды во главе с командующим М.А. Матюшкиным взяли город Баку (Шереметев, 1914, с. 281). Таким образом, молодая Российская империя в течение 1722-1723 гг. заняла стратегически и экономически значимые пункты на юго-западном побережье Каспийского моря. С подписанием 12 сентября 1723 г. Петербургского договора с Сефевидским Ираном Россия на международном уровне юридически закрепила за собой указанные территории (Русско-дагестанские отношения, 1958, с. 284-287). Хотя Петербургский договор Сефевидами не был ратифицирован, но Российская империя фактически владела данным регионом.

Персидский поход Петра Великого 1722-1723 гг. и его итоги в свою очередь активизировали кавказскую политику Османской империи. Петр I осознавал, что успехи России в Кавказско-Каспийском регионе неизбежно приведут к осложнению отношений с османскими властями, и поэтому заблаговременно принял меры для смягчения позиции османов. 20 июня 1722 г. перед началом похода российскому резиденту в Стамбуле И.И. Неплюеву был послан рескрипт с предписанием объявить туркам о походе российских войск в Западный Прикаспий с целью наказания виновников (дагестанских правителей Сурхай-хана Казикумухского и Хаджи-Давуда) шемахинского погрома 1721 г. (Курукин, 2010, с. 101-102), в результате которого пострадало очень много русских купцов.

Марш Петра Великого с момента высадки войск на Аграхани и вплоть до Дербента происходил без каких-либо демаршей со стороны османов. Однако в работах отдельных историков утверждается, что одной из причин того, что поход был неожиданно прерван, было намерение избежать преждевременной войны с Турцией (Маркова, 1966, с. 27). Другие историки-кавказоведы даже отмечают прибытие в лагерь российских войск на р. Милюкент под Дербентом османского представителя (кто именно, не уточняется), потребовавшего прекратить поход под угрозой начала войны (Сотавов, 1991, с. 60; Рахаев, 2012, с. 164).

С подобным утверждением видный российский историк И.В. Курукин, которому не удалось обнаружить документальных данных о прибытии в лагерь Петра I южнее Дербента кого-либо из османских дипломатов, абсолютно не согласен (Курукин, 2010, с. 102). Автору данной статьи, в последние годы 
работающему с документами различных фондов, в частности, с «Кабинетом Петра Великого» (Ф. 9) РГАДА, «Канцелярией генерал-адмирала Ф.М. Апраксина» (Ф. 233) РГАВМФ и др., также не удалось найти на сей счет каких-либо документальных данных. Более того, следует заметить, что вопрос о демарше османов не обсуждался на состоявшемся 29 августа 1722 г. военном совете в лагере вблизи Дербента, на котором и было принято окончательное решение приостановить поход. Все эти мнения высшего военного руководства приведены в Походном журнале 1722 года (Походный журнал, 1855). Таким образом, в качестве главной причины приостановки похода можно назвать утрату продовольствия, запасов которого оставалось ровно на месяц, в результате кораблекрушений в районе Аграханского залива и в устье р. Милюкент.

Между тем, когда весть о Персидском походе дошла до Стамбула, там распространились слухи о появлении русских в Грузии и Ширване (Мустафаев, 1993, с. 54). Недовольство османских властей действиями России на Кавказе подогревалась английской дипломатией, преследовавшей собственные цели в бассейне Каспийского моря. И.И. Неплюев с целью исключить подозрения предложил османскому султану отправить в Россию своего посланника, что и было сделано (Курукин, 2010, с. 102). Зимой 1722-1723 гг. в Москву явились османские послы Нишли Мехмет-ага и Осман-ага, которых принял только что вернувшийся из похода император Петр Великий. Послам было заявлено о нежелании нарушить мир с османами и озвучено предложение о возможном разделе Сефевидского Ирана (Курукин, 2010, с. 103). Когда было получено достоверное известие о возвращении Петра I из Дербента в Петербург, османские правящие круги в какой-то мере успокоились (Соловьев, 1993, c. 385).

В дальнейшем начались долгие и изнурительные переговоры, несколько раз прерванные без результата и порою доходившие до угроз войны. Османская сторона требовала, чтобы Россия оставила занятые ею города и области на юго-западном побережье Каспия, поскольку она, как считали османы, не имеет никаких прав на прикаспийские провинции. Позиция России была ясна - никоим образом не допустить османов к Каспийскому морю. Об этом решительно заявил в Константинополе российский резидент И.И. Неплюев (Соловьев, 1993, с. 388).

Посредником в переговорах выступил французский посол в Константинополе де Бонак. Хотя И.И. Неплюев не очень-то был доволен его посреднической ролью, но позиция французской дипломатии в этом вопросе, в отличие от Англии, была направлена на мирное решение проблемы. Сам И.И. Неплюев в письме вынужден был признать, что «больше того ныне без войны получить нельзя» (Соловьев, 1993, с. 391).

Окончательный вариант договора, раз десять исправленный ранее, наконец, был подготовлен. 12 июня 1724 г. Константинопольский договор был подписан, а затем и ратифицирован обеими сторонами. По условиям договора 
на землях к западу от Каспийского моря устанавливалась общая граница между Российской и Османской империями. Первая статья договора содержала процедуру демаркации кавказских территорий между двумя странами. Расстояние от города Шемахи до Каспийского побережья по времени езды («среднею ездою») прямою дорогою делилось на три равные части; там, где заканчивалась две трети от берега в сторону Шемахи, планировалось поставить разграничительный знак. Затем от Дербента на 22 часа езды в сторону материка ставился другой знак, оба знака соединялись прямой линией, которая продолжалась до места слияния рек Аракса и Куры, считавшееся конечным пунктом российско-османской границы (Русско-дагестанские отношения, 1958, с. 298). Территория по левую сторону, в сторону моря от этой прямой линии, принадлежала России, а правая часть - Османской империи.

В процессе архивно-эвристической работы по теме проекта РФФИ «Петр Великий в исторической судьбе Кавказско-Каспийского региона» в архивах России в РГВИА в фонде 846 нами была выявлена составленная геодезистами Петровской эпохи карта с указанием демаркации кавказских территорий между Российской и Османской империями, которая называется «Карта о границе, сочиненной в Ширвани» (РГВИА, ф. 846, оп. 16, д. 20501, л. 18). Археографическое описание карты был осуществлен Л.А. Гольденбергом (Гольденберг, 1964, с. 120.), но сама карта не была издана. На данной карте обозначена часть Каспийского моря от Дербента до Баку и прилегающая с запада к морю территория. Красной прямой линией на карте очерчена граница между двумя государствами в соответствии с теми условиями, которые содержит первая статья Константинопольского договора 1724 г. Большие красные точки на этой линии обозначают поставленные пограничные знаки. Пунктирная красная линия позади Дербента и от реки Самур означает, что демаркация границы еще не закончена в этой зоне.

Как видно на карте (см. Рисунок 1), в Дагестане под власть османов переходили владения Сурхай-хана Казикумухского, общество Ахты-пара и часть общества Алты-пара в верховьях р. Самур, а остальная часть Дагестана была признана за Россией. Под османской «порцией» также признавались Грузия и Ереванская провинция. Что касается Ширванской провинции с городом Шемаха, то она передавалась под власть Хаджи-Давуда под протекторатом Османской империи. К этому времени Хаджи-Давуд был уже принят в подданство османов (Сотавов, 1991, с. 62). 


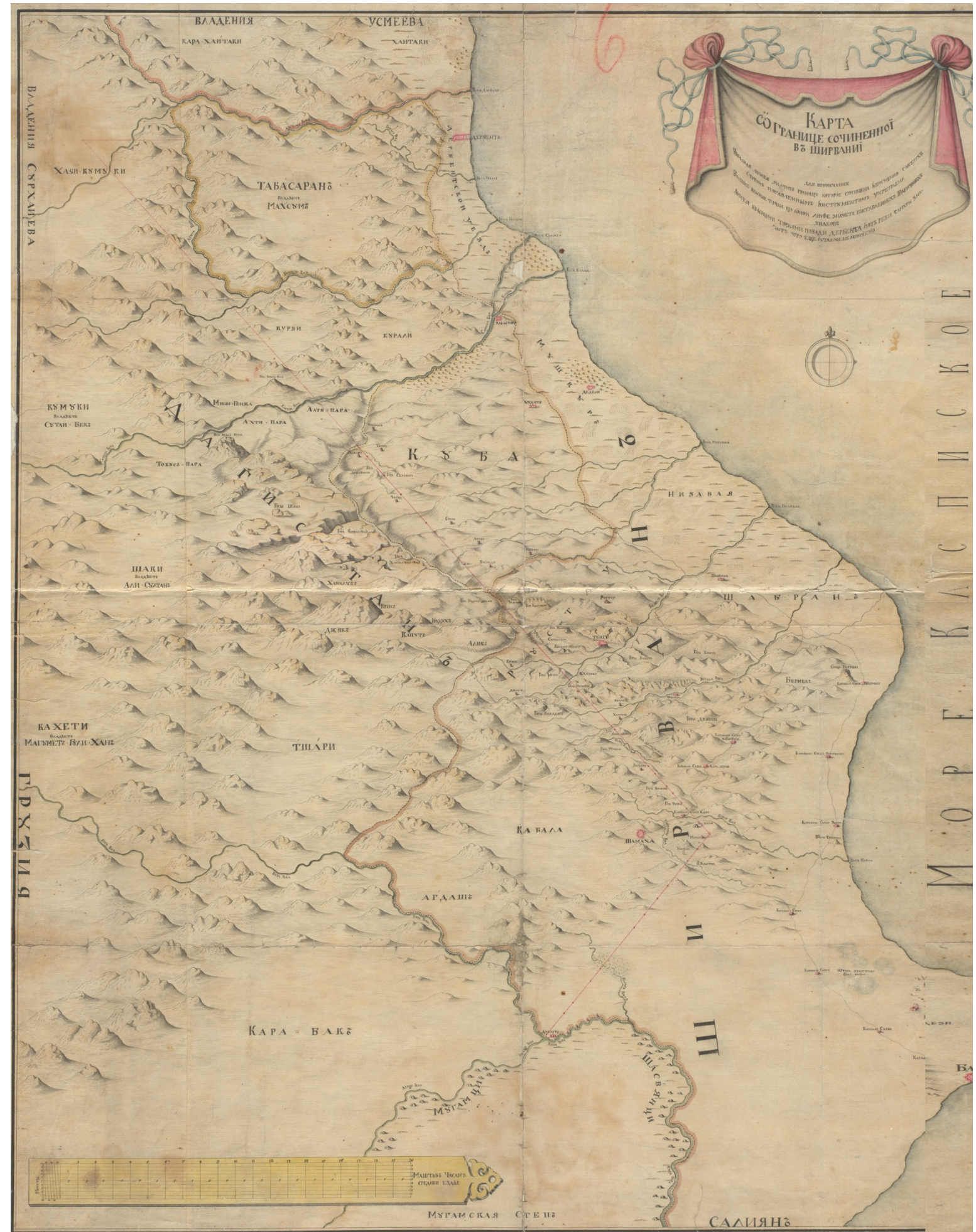

Рисунок 1. Карта демаркации российско-османской границы в Восточном Закавказье в 20-е гг. XVIII в. (РГВИА. Ф. 846. Оп. 16. Д. 20501. Л. 18.)

Figure 1. Maps with indication of demarcation of the Russian-Ottoman border in the East Transcaucasia in 1720s. 
Россия закрепила за собой узкую полосу завоеванных прикаспийских областей и, самое главное, не допустила османов к берегам Каспийского моря, что изначально и планировалось российской дипломатией (Лысцов, 1951, с. 136). Дагестанское побережье Каспия от р. Терек до города Дербента вообще не обсуждалось и не упоминалось в договоре, что можно расценивать как фактическое признание прав Российской империи на эту территорию Дагестана.

Третьей статьей Константинопольского договора определялись османо-сефевидские границы: Ардебиль оставался во власти шаха, который должен был служить своего рода барьером, отделявшим российские территории от османских. Под владения Османской империи переходили Тебриз с большей частью его провинции, Хамадан и Керманшах, а также города и провинции Гянджа, Бердаа, Карабах, Нахичевань (Русско-дагестанские отношения, 1958, с. 300). Далее предстояла сложная процедура демаркации российско-османской границы с участием комиссаров обеих сторон, продолжавшаяся вплоть до 1728 г., поскольку османы своими необоснованными притязаниями затягивали работу комиссии (Мустафаев, 1993, с. 89).

Таким образом, Персидский поход 1722-1723 гг. и подписанные по его результатам Петербургский договор 1723 г. и Константинопольский договор 1724 г. кардинально изменили геополитическую ситуацию в регионе на территории, расположенной к западу от Каспийского моря. Главным геополитическим событием явилось появление и утверждение в регионе нового «игрока» в лице молодой Российской империи, поставившей под свой контроль морские коммуникации и области, пролегавшие вдоль западного и южного побережий Каспия.

В пространстве межгосударственного противостояния Российской и Османской империй впервые в истории Западного Прикаспия была установлена российско-османская граница, разделившая народы и общества без учета исторически сложившихся традиций ведения хозяйства. Новая пограничная линия послужила своего рода «барьером» между народами региона, связанными между собой тесными этнокультурными и экономическими контактами, расколола исторически формировавшиеся кавказские и персидские общества. Местные пограничные сообщества и их элиты неволею судьбы оказались втянуты в непростые российско-османские отношения. Подобное деление кавказских территорий привело к затяжной конфликтной ситуации в пограничной зоне, к сложной и изменчивой пограничной жизни.

Напряженность в российско-османской пограничной линии создавалось антироссийскими действиями Хаджи-Давуда, назначенного османским двором правителем Ширвана (Бутурлин, 1823, с. 52). Последний занял антироссийскую позицию и неоднократно предпринимал походы вместе с уцмием Кайтага против расквартированного в Дербенте российского гарнизона. Даже после определения российско-османских границ Хаджи-Давуд продол- 
жать претендовать на территории в российской зоне влияния (РГАДА, ф. 9, оп. 4 , д. 72, л. 229-230). В то же время он информировал дербентского коменданта А.Т. Юнгера о положении турецких войск в районе Гянджи (РГАДА, ф. 9, оп. 4, д. 74, л. 836-837 об.), где находилось командование турецкими войсками. Расположенная в российской «порции» крепость Денге (Тенге) в Кубинской провинции была им занята и укреплена каменною стеною в 1724 г. Он подкупил «пашу, чтоб ныне границы не окончал», заплатив, по данным И.И. Неплюева, «12 тысяч туманов», что составляло российскими «деньгами 120 тысяч рублей» (Сотавов, 1991, с. 75). Командующий османскими отрядами в Гяндже Мустафапаша отозвал турецких комиссаров до весны 1727 г., в это время Хаджи-Давуд и турки пытались переселить в свои владения жителей из российской зоны. Генерал-лейтенанту А.И. Румянцеву пришлось осадить крепость Денге и выбить оттуда Хаджи-Давуда еще до окончания разграничения российскоосманских границ (Гербер, 1958, с. 92).

Активным участником событий в российско-османской пограничной зоне являлся Сурхай-хан Казикумухский, претендовавший на роль политического лидера на Северо-Восточном Кавказе. Разграничение территорий между Россией и Османской империей коснулось и владений Сурхай-хана, который так и не допустил разделения своих владений, и

«турки ево к тому принуждать не хотят и не смеют и объявили России, что она вольна у Зурхая землю силою взять» (Курукин, 2010, с. 251).

Назначенный российским комиссаром при разграничении российскоосманских земель генерал-майор А.И. Румянцев 24 февраля 1728 г. докладывал, что демаркация границ между двумя империями во владениях Сурхай-хана, в которой с российской стороны участвовал майор И. Гербер, еще не завершена (Сборник Императорского Русского исторического общества, 1888, с. 50).

Учитывая роль Сурхай-хана на Северо-Восточном Кавказе, как одного из сильных владетелей, и Россия, и Османская империя пытались привлечь его на свою сторону. Сурхай-хан значительное время успешно лавировал между ними, и как только

«турки в 1727 г. ему прислали пашинской чин и к тому на знак два года или бунчук и жалованье 3000 руб. на год и к тому же отдали уезд Кабалу, то он турецкую сторону принял и им учинил» (Гербер, 1958, с. 103).

Османским правящим кругам Сурхай-хан показался более действенным владетелем, чем Хаджи-Давуд, и было принято решение назначить правителем Ширвана Сурхай-хана. В 1728 г. Хаджи-Давуд был арестован и переведен в Эрзурум, а оттуда сослан на остров Родос в Эгейском море, где он и умер (Сотавов, 1991, с. 76).

Однако отстранение Хаджи-Давуда не привело к стабилизации политической ситуации в пограничной зоне. Теперь Сурхай-хан, подстрекаемый османами и располагавший внушительными военными силами, претендовал на 
«куралинские» (лезгинские - авт.) земли в бассейне реки Самур (Сотавов, 1991, с. 76), которые находились в российской зоне влияния. Османские власти, по донесению командующего войсками в Гяндже Мустафы-паши, объявляли И.И. Неплюеву о том, что «народ курали имянуемой издревле есть верное войско Сурхаева и господа российские не могут претендовать оного народа, и тот ли народ или дагистанской похотел бы к Сурхаю идти, дабы от российской стороны воспрещения не было» (ЦГАРД, ф. 301, оп. 1, д. 12, л. 1). И.И. Неплюеву пришлось возразить на это: «о куралинском народе... оной никогда от Сурхая не депендовал и по трактату в порцию российскую надлежит» и потребовать «у Порты, чтоб они прислали указ к паше своему, чтоб он о том сам не веря Сурхаю по силе трактата с помянутым генералом согласился или б нарочно от обоих стран послали комиссаров» (л. 2).

В декабре 1728 г. Сурхай-хан с войском вторгся в российские пределы: на Муганскую степь и в Сальянскую провинцию, и, разорив эти области, с награбленным имуществом ушел к себе. К тому же дядя Сурхай-хана, Карат-бек, вступив в российскую зону в Дагестане, увел с собой около трех тысяч человек, «отвращая оных от подданства России, призывая в Сурхаеву службу» (Курукин, 2010, с. 252). Румянцев, опасаясь начала военных действий с османами в случае быстрых ответных мер против Сурхай-хана, отправил гонцов с протестом в Гянджу и Стамбул. В ответ получил «оговорки» о том, что границы еще «не окончаны», а Сурхай-хан находится «не в совершенном послушании» (Сотавов, 1991, с. 79). Видя бездействие со стороны османских властей, в итоге командующий решил наказать Сурхай-хана и отправил в поход в его владения бригадира Л.Я. Соймонова с драгунами, откуда отогнано было около 30 тыс. «сурхаевых баранов» (Курукин, 2010, с. 252). Несмотря на требования османов, имущество Сурхай-хану не было возвращено, да и сам Сурхай-хан также не вернул награбленного в Мугани и в Сальянах добра (c. 254).

И в дальнейшем Сурхай-хан продолжал нагнетать ситуацию и создавать напряженность в пограничной зоне, где продолжались демаркационные работы. Несмотря на то, что османы посоветовали хану не вмешиваться в российские дела, он продолжал претендовать на ряд приграничных деревень в Кубинской провинции. 16 марта 1732 г. генерал В.Я. Левашов, осведомленный о планах Сурхай-хана напасть на указанные деревни, написал командующему османскими войсками Али-паше в Гянджу письмо с просьбой воздействовать на Сурхай-хана, чтобы он отказался от похода (Западный Прикаспий в составе Российской империи, 2020, с. 269-272). Спустя два дня, 18 марта аналогичное письмо было отправлено с толмачами самому Сурхай-хану в Казикумух (ЦГАРД, ф. 18, оп. 1, д. 90, л. 8-9).

Командующий османскими войсками Али-паша прислал ответ, что они о планах Сурхай-хана «ничего не слыхали, может некоторые недоброжелатели о том напрасно доносят... понеже Сурхай хан противно мира поступать и 
нарушителем быть не смеет» (л. 10-11). Прибывшие вслед за ответом османской Али-паши от Сурхай-хана толмачи объяснили, что «он ссорится за малое дело не желает», поскольку его секретарь известил его «о доходах тех деревень», с которых собирается ежегодно 15 руб., и «Сурхай сказал за 15 руб. ссорится не будет, хотя теми деревнями и россияне завладеют, токмо он желает, чтобы ведали о ево правой претензии» (л. 1-11). Видимо, на этот раз убедить Сурхай-хана отказаться от планов совершить поход в российские пределы В.Я. Левашову удалось, или же, скорее, Сурхай-хан извлек уроки из предыдущего похода, за которым последовал ответный карательный поход российских войск в его владения.

Сменивший в феврале 1726 г. в должности командующего Низовым корпусом больного генерала М.А. Матюшкина князь В.В. Долгоруков, объездив весь юго-западный берег Каспия с севера на юг от крепости Святого Креста до Решта, остался крайне недоволен состоянием российских войск в регионе.

«Как на Сулаке (крепость Святого Креста. - авт.), так и в Дербени безнадежны командиры» (РГАДА, ф. 9, оп. 4, д. 77, л. 1032),

- заключал В.В. Долгоруков. Уловив психологию и нравы дагестанцев, новый командующий в донесении кабинет-секретарю А.В. Макарову от 21 сентября 1726 г. рекомендовал в целях «государственного интересу, чтоб были здесь (в Дагестане. - авт.) командиры добрые», и просил командировать в регион для назначения на ответственные должности исключительно генералов, поскольку «где имя генеральское помянетца, то и боятца, а ежели где полковник или подполковник комендантом... страху от него не имеют и в дело ево не ставят, и называют ево по их босурманскому обычаю маленькой господин» (л. 1032).

Кроме пресечения антироссийских действий кавказских владетелей в пограничной зоне, находящихся под протекторатом османов, российской администрации крайне необходимо было прочно утвердиться и на завоеванной прикаспийской узкой полосе, выстраивать отношения с представителями местных политических элит. Ранее формально признавшим российскую власть кавказским владетелям теперь приходилось непосредственно вступать в контакт с российскими представителями, выполнять определенные обязательства перед ними и отказываться от самостоятельных решений во внешних делах.

Очевидно, что новые правила не устраивало даже тех, которые во время похода проявили лояльность и продемонстрировали личную покорность Петру Великому. Так, союзник Петра I в Дагестане шамхал Тарковский Адиль-Гирей решил в конце 1724 г. выступить против российской администрации (РГВИА, ф. 20, оп. 1/47, д. 4. л. 19-20). Причин выступления шамхала против российских властей, очевидно, было несколько. Во-первых, строительство в непосредственной близости его владений на реке Сулак новой крепости 
Святого Креста - нового русского форпоста на Северном Кавказе. Теперь все действия шамхала Адиль-Гирея были полностью подконтрольны российской администрации. Во-вторых, шамхал разочаровался в действиях российских властей, не утвердивших его исключительную роль, как этого он сам просил, среди остальных дагестанских владетелей (Русско-дагестанские отношения, 1988). Не было также удовлетворена просьба шамхала об установлении его власти над кочевавшими в районе Сулака ногайцами. Видимо, Адиль-Гирей, не получив желаемого статуса и видя достаточно выгодное положение других дагестанских владетелей Сурхай-хана и Хаджи-Давуда под протекторатом султана, фактически считавшимися независимыми правителями, решил отречься от России. Также следует отметить старания османских властей в антироссийской деятельности шамхала. Как следует из архивных источников, Адиль-Гирей поддерживал контакты с османской стороной (РГАВМФ, ф. 233, оп. 1, д. 222а. л. 116, 136 и об.). Еще 10 октября 1723 г. М.А. Матюшкин доносил генерал-адмиралу Ф.М. Апраксину, что эрзурумский Ибрагим-паша прислал письмо Адиль-Гирею, о котором сам шамхал сообщил коменданту крепости Святого Креста бригадиру Л.Я. Соймонову (РГАВМФ, ф. 233, оп. 1, д. 222а, л. 116).

Тарковский шамхал Адиль-Гирей пытался склонить к антироссийским выступлениям и остальных дагестанских правителей - Сурхай-хана, ХаджиДавуда, уцмия Ахмед-хана, Султана Мамута аксаевского, Айдемира эндиреевского, и тем самым организовать общедагестанское выступление против российских властей. Во владениях шамхала Адиль-Гирея распространились слухи о тяжелом положении русского гарнизона в крепости Святого Креста, Терках и Аграханском ретраншементе, «якобы у нас (русских. - авт.) провианта не имеется и едят токмо размешав на воде жидко муку, отчего у нас якобы великой мор происходит и на каждый день помирает человек по сто и больше... к тому ж все тарковские жители говорят ныне де у русских людей гауров государь (Петр I. - авт.) умер, чему как Адиль-Гирей шамхал, так и прочие тарковские жители рады, в великом веселии состоят и между собою говорят, ныне де некому от нас идти охранить и будем всемерно стараться, чтоб их города все взять и людей вырубить, а ежели тех городов достать нам будет невозможно, то будут под ними стоять до того времени, когда русские люди от голода помрут» (РГАДА, ф. 9, оп. 4, д. 72, л. 229-230 об.).

Однако дагестанские владетели не поддержали шамхала Адиль-Гирея.

«К нему присоединились только несколько тавлинцев (горцев. - авт.); другие же, опасаясь наказания, какое неминуемо должны были понести шамхаловы подданные, оставались в покое» (Бутурлин, 1832),

- отмечает Д.П. Бутурлин.

За антироссийскую деятельность шамхал Адиль-Гирей 21 мая 1726 г. был пленен (РГВИА, ф. 20, оп. 1/47, д. 9, л. 81-82 об.) и, после недолгого содержания в крепости Святого Креста, по решению нового командующего Низовым 
корпусом В.В. Долгорукова, был отправлен в Архангелогородскую губернию, где в январе 1732 г. скончался (РГАДА, ф. 248, оп. 13, д. 781, л. 85 и об.). Звание шамхала, «казавшееся слишком опасным по сильному влиянию, какое носившия оное лица имели на дагестанские народы», было упразднено, однако доходы с владений шамхала были оставлены за его сыновьями и «некоторым старшинам из сего народа, по взятии от них в крепость Святого Креста аманатов» (Бутков, 1869, с. 83).

Российско-османское пограничье сохранялось до первой половины 30-х гг. XVIII в. По условиям Рештского договора 1732 г. Россия оставила Гилян, Мазендеран и Астрабад, а в 1735 г. по Гянджинскому трактату - весь Азербайджан и Дагестан, вернувшись за р. Терек, где проходили новые российские границы (ПСЗ РИ, 1830, с. 494). Россия, пришедшая в прикаспийский регион в 1722 г., спустя 13 лет, в 1735 г., покинула регион, чтобы снова вернуться сюда, в Дагестан и Азербайджан, в начале XIX в.

\section{Выводы}

Проведенное исследование позволило обозначить и изучить новый сюжет восточной политики Петра Великого, связанный с установлением российскоосманского пограничья (фронтир) в Западном Прикаспии. Возникновение российско-османской пограничной линии явилось следствием Персидского похода Петра Великого 1722-1723 гг. и заключения Константинопольского договора 1724 г. Геополитическое положение на Восточном Закавказье в исследуемый период кардинально изменилось в связи с появлением здесь нового политического «игрока» в лице молодой Российской империи; регион превратился в арену жесткого политико-дипломатического противостояния между Российской и Османской империями. Разрешением противостояния стало установление пограничной зоны. На основании выявленной и впервые публикуемой «Карты о границе, сочиненной в Ширвани» из фондов РГВИА, составленной геодезистами Петровской эпохи, удалось показать сложную процедуру демаркации российско-османской границы на землях к западу от Каспийского моря, проводимой по условиям Константинопольского договора 1724 г. Новая пограничная линия, разделившая исторически формировавшиеся кавказские и персидские общества без учета сложившихся традиций ведения хозяйства и этнокультурных контактов, привела к сложной и изменчивой пограничной жизни в регионе. Местные общества и их элиты, оказавшись по обе стороны пограничья, не стали мириться с новым порядком. Изучение политических и поведенческих действий различных акторов пограничной зоны позволяет выяснить их отношение к появлению в Западном Прикаспии Российской и Османской империй. Полученные научные результаты с точки зрения гуманитарного знания носят уникальный характер и могут быть востребованы при дальнейшей разработке российскими и зарубежными исследова- 
телями других сюжетов внешней политики Российской и Османской империй XVIII в.

\section{Благодарности}

Работа выполнена при финансовой поддержке РФФИ в рамках научного проекта № 20-09-42023 «Петр Великий в исторической судьбе КавказскоКаспийского региона».

\section{Список литературы}

Бутков, П. Г. (1869). Материалы для новой истории Кавказа с 1722 по 1803 год. Часть І. Типография Императорской академии наук.

Бутурлин, Д. П. (1823). Военная история походов россиян в XVIII в. Часть II. Печатано в Военной типографии Главного штаба Его Императорского Величества.

Гербер, И. Г. (1958). Описание стран и народов вдоль западного берега Каспийского моря. 1728 г. В М. О. Косвен (Ред.), История, география и этнография Дагестана XVIII-XIX вв. (сс. 60-120). Издательство восточной литературы.

Гольденберг, Л. А. (1964). Рукописные карты и планы XVIII в. Как источник по истории города Дербента. В Археографический ежегодник за 1963 г. (сс. 244-253). Наука.

Западный Прикаспий в составе Российской илперии (1722-1735 г2.). Сборник архивных документов. (2020). МавраевЂ.

Курукин, И. В. (2010). Персидский поход Петра Великого. Низовой корпус на берегах Каспия (17221735). Квадрига; Объединенная редакция МВД России.

Лысцов, В. П. (1951). Персидский поход Петра I. 1722-1723. МгУ.

Маркова, О. П. (1966). Россия, Закавказъе и международные отношения XVIII в. Наука.

Мустафазаде, Т. Т. (1993). Азербайджан и русско-турецкие отношения в первой половине XVIII в. Элм.

Полное собрание законов Российской илперии (ПСЗ РИ) (Т. 9). (1830). Типография ІІ Отделения Собственной его императорского величества канцелярии.

Походный журнал 1722 года. (1855). б.и.

Рахаев, Дж. Я. (2012). Политика России на Северном Кавказе в первой четверти XVIII века. Источники. Архивные и нарративные источники 1699-1725 годов, российско-османские и российско-персидские договоры первой четверти XVIII века. Русский фонд содействия образованию и науке.

Российский государственный архив военно-морского флота (РГАВМФ). (б. д.-а). Ф. 233. Оп. 1. Д. 211.

Российский государственный архив военно-морского флота (РГАВМФ). (б. д.-b). Ф. 233. On. 1. Д. 213.

Российский государственный архив военно-морского флота (РГАВМФ). (б. д.-с). Ф. 233. Оп. 1. Д. $222 a$. 
Российский государственный архив древних актов (РГАДА). (б. д.-а). Ф. 9. Оп. 4. Д. 63.

Российский государственный архив древних актов (РГАДА). (б. д.-b). Ф. 9. Оп. 4. Д. 72.

Российский государственный архив древних актов (РГАДА). (б. д.-с). Ф. 9. Оп. 4. Д. 74.

Российский государственный архив древних актов (РГАДА). (б. д.-d). Ф. 9. Оп. 4. Д. 77.

Российский государственный архив древних актов (РГАДА). (б. д.-е). Ф. 248. Оп. 13. Д. 781.

Российский государственный военно-исторический архив (РГВИА). (б. д.-а). Ф. 20. On. 1/47. Д. 4.

Российский государственный военно-исторический архив (РГВИА). (б. д.-b). Ф. 20. On. 1/47. Д. 9.

Российский государственный военно-исторический архив (РГВИА). (б. д.-с). Ф. 846. On. 16. Д. 20501.

Русско-дагестанские отношения в XVIII - начале XIX в. Сборник документов. (1988). Наука.

Русско-дагестанские отношения XVII - первой четверти XVIII в. Документы и материалы. (1958). Дагестанское книжное издательство.

Сборник Илператорского Русского исторического общества (Т. 101). (1888). б.и.

Соловьев, С. М. (1993). Сочинения. Книга IX (Тт. 17-18). Мысль.

Сотавов, Н. А. (1991). Северный Кавказ в русско-иранских и русско-турецких отношениях в XVIII в. Наука.

Центральный государственный архив Республики Дагестан (ЦГАРД). (б. д.-а). Ф. 18. On. 1. Д. 90.

Центральный государственный архив Республики Дагестан (ЦГАРД). (б. д.-b). Ф. 301. On. 1. Д. 12.

Шереметев, П. С. (1914). Владимир Петрович Шереметев. 1668-1737. Синодальная Типография.

\section{References}

Butkov, P. G. (1869). Materials for a new history of the Caucasus from 1722 to 1803. Part I. Print shop of the Imperial Academy of Sciences. (In Russian).

Buturlin, D. P. (1823). A Military History of the Russian Campaigns in the 18th Century. Part II. Printed in the Military Printing Office of His Imperial Majesty's General Staff. (In Russian).

Central State Archive of the Republic of Dagestan (CSARD). (n. d.-a). F. 18. In. 1. C. 90. (In Russian).

Central State Archive of the Republic of Dagestan (CSARD). (n. d.-b). Ф. 301. In. 1. C. 12. (In Russian).

Collection of the Imperial Russian Historical Society (Vol. 101). (1888). n.p. (In Russian).

Complete Collection of Laws of the Russian Empire (Vol. 9). (1830). Printery of the 2nd Department of His Imperial Majesty's Own Chancellery. (In Russian).

Gerber, I. G. (1958). Description of countries and peoples along the western shore of the Caspian Sea. 1728. In M. O. Kosven (Ed.), History, geography and ethnography of Dagestan in the 18th and 19th centuries. (pp. 60-120). Oriental Literature Publishers. (In Russian).

Goldenberg, L. A. (1964). Handwritten maps and plans of the 18th century as a source for the history of the city of Derbent. In Archaeographical Yearbook 1963. (pp. 244-253). Nauka. (In Russian). 
Kurukin, I. V. (2010). Peter the Great's Persian campaign. Lower Corps on the shores of the Caspian Sea (1722-1735). Quadriga; Joint Editorial Board of the Russian Ministry of Internal Affairs. (In Russian).

Lystsov, V. P. (1951). Peter the Great's Persian campaign. 1722-1723. Moscow State University Press. (In Russian).

Markova, O. P. (1966). Russia, the Transcaucasus and international relations in the 18th century. Nauka.

Mustafazadeh, T. T. (1993). Azerbaijan and Russian-Turkish relations in the first half of the 18th century. Elm. (In Russian).

Rakhayev, J. Y. (2012). Russian policy in the North Caucasus in the first quarter of the 18th century. Sources. Archival and narrative sources 1699-1725, Russian-Ottoman and Russian-Persian treaties of the first quarter of the 18th century. Russian Foundation for the Promotion of Education and Science. (In Russian).

Russian State Archive of Ancient Documents (RSAAD). (n. d.-a). F. 9. In. 4. C. 63. (In Russian). Russian State Archive of Ancient Documents (RSAAD). (n. d.-b). F. 9. In. 4. C. 72. (In Russian). Russian State Archive of Ancient Documents (RSAAD). (n. d.-c). F. 9. In. 4. C. 74. (In Russian). Russian State Archive of Ancient Documents (RSAAD). (n. d.-d). F. 9. In. 4. C. 77. (In Russian). Russian State Archive of Ancient Documents (RSAAD). (n. d.-e). F. 248. In. 13. D. 781. (In Russian). Russian State Military Historical Archive (RSMHA). (n. d.-a). F. 20. In. 1/47. C. 4. (In Russian). Russian State Military Historical Archive (RSMHA). (n. d.-b). F. 20. In. 1/47. C. 9. (In Russian). Russian State Military Historical Archive (RSMHA). (n. d.-c). F. 846. In. 16. C. 20501. (In Russian). Russian State Navy Archive (RSNA). (n. d.-a). F. 233. In. 1. C. 211. (In Russian).

Russian State Navy Archive (RSNA). (n. d.-b). F. 233. In. 1. C. 213. (In Russian).

Russian State Navy Archive (RSNA). (n. d.-c). F. 233. In. 1. C. 222a. (In Russian).

Russian-Dagestan relations in the 17th century and the first quarter of the 18th century. (1958). Dagestan book publishing house. (In Russian).

Russian-Dagestan relations in the 18th and early 19th centuries. (1988). Nauka. (In Russian).

Sheremetev, P. S. (1914). Vladimir Petrovich Sheremetev. 1668-1737. Synodal Typography. (In Russian).

Soloviev, S. M. (1993). Essays. Book IX (Vols. 17-18). Mysl. (In Russian).

Sotavov, N. A. (1991). The North Caucasus in Russo-Iranian and Russo-Turkish relations in the $18^{\text {th }}$ century. Nauka. (In Russian).

The marching journal of 1722. (1855). n.p. (In Russian).

The Western Caspian region as part of the Russian Empire (1722-1735). Collection of archival documents. (2020). Mavraev. (In Russian). 